Available online:

http://journal.imla.or.id/index.php/arabi

Arabi : Journal of Arabic Studies, 2 (2), 2017, 163-171

DOI: http://dx.doi.org/10.24865/ajas.v2i2.55

\title{
USHUL AL-NAHWI DALAM PERSPEKTIF IBN MADHA
}

\author{
Wati Susiawati \\ Universitas Islam Negeri Syarif Hidayatullah Jakarta, Indonesia \\ E-mail : wati.susiawati@uinjkt.ac.id
}

\begin{abstract}
Ibn Madā was one of famous Nuhat figures in his time. This is caused by his contradictive ideas between the other Nuhat in his time as stated in his book "al-Radd' Alà al-nuhät". In this paper, the authors wants to expose and describe the thoughts he has in studies of usūl al-nahwi. Ushūl al-nahwi consists of four components, namely: qiyās, ta' 'Til, ta'wīl and 'āmiles. In terms of qiyās, Ibn Mada expressly reject qiyās aqli. Also, in terms of ta'Til, Ibnu Madāa received only the ta'Til Ülà and does not accept the ta'Til thawäni. Significantly, the method of ta'wil in sintaxis sciences includes into the concept of hadhaf (deletion), istitär (concealment) and taqdir (estimation) in a sentence, and Ibnu Madāa also did not accept them. In terms of 'āmiles, Ibn Madà also does not accept the existence of 'amil lafzi. That is the rejection of Ibnu Mada against practices qiyās, ta'Til, ta'wìl and 'àmiles, because Ibnu Maḍā rests on what is called sima'i by nuhā $t$.
\end{abstract}

Keywords: Ibnu Mạ̣ā, al-Radd 'alā al-nuhàt, qiyās, ta'Tì (illah ), ta'wīl and 'àmil

\begin{abstract}
Abstrak
Ibn Madha merupakan salah satu tokoh nuhāt yang sangat terkenal pada masanya. Hal ini disebabkan oleh pemikiran-pemikirannya yang cenderung kontradiktif dengan para nuhāt pada masanya sebagai mana tertuang dalam karya besarnya "al-Radd 'Alā alNuhăt". Dalam tulisan ini, penulis memaparkan dan mendeskripsikan pemikiranpemikirannya dalam kajian ușūl al-nahwwi. Ușūl Al-Naḥwi terdiri dari empat komponen, yaitu: qiyās, ta'î̀l (illah), ta'wīl dan 'ämil. Dalam hal qiyās, Ibn Madha secara tegas menolak qiyās aqli. Begitu juga dalam hal illah, Ibn Madha hanya menerima Illah ŪTa dan tidak menerima illah thawānî. Secara nyata, metode ta'wīl dalam ilmu nạ̣wu menjelma menjadi konsep hadhaf (pembuangan), istitär (penyembunyian) dan taqdir (pengiraan) dalam sebuah kalimat, dan Ibnu Madha juga tidak menerima hal tersebut. Dalam hal 'āmil, Ibnu Madha juga tidak menerima adanya āmil lafẓi. Begitulah penolakan Ibnu Madha terhadap praktik qiyās, illah, àmil dan ta'wïl. Pandangan Ibn Madha berpijak pada apa yang oleh kalangan nuhät disebut dengan samā'i.
\end{abstract}

Kata Kunci: Ibn Madha, al-Radd 'alā al-nuḥāt, qiyās, ta'Til (illah ), ta'wīl dan 'āmil 


\section{Arabi : Journal of Arabic Studies}

\section{Pendahuluan}

Sebagaimana dalam kajian uṣūl fiqh, istilah ushul juga dipergunakan oleh para ahli bahasa dalam ilmu nahwu. Kata ushul dan nahwu dirangkai satu sehingga menjadi istilah Ushul al-Nahwi. Sebagaimana peran penting Ushul Fiqh dalam kajian Fiqh, Ushul al-Nahwi juga mempunyai peran yang sangat signifikan dalamilmu nahwu.

Sejak abad ke-2 H. para ulama nahwu sudah merasakan perlu adanya nahwu tanpa analisis yang filosofis yang gampang dipelajari. Untuk tujuan ini, maka timbullah karya al-Jahiz dan lainlain yang berupa mukhtasharat (kitab-kitab ringkas). Kemudian pada abad ke-6 H, muncullah Ibn Madha. Dia adalah salah satu tokoh nuhăt yang turut meramaikan kajian Ușül al-nahwi dengan corak pemikiran dan kontribusinya yang khas. Ibn Maḍā melalui karya besarnya "al-Radd 'alā alNuhăât' berupaya merampingkan kajian ilmu nahwu yang berintikan penolakan pada penggunaan teori 'āmil dalam analisis i'rāb.

\section{Dinamika Sosial dan Intelektual Ibnu Maḍā}

Ibn Madha lahir di Qordova pada tahun $513 \mathrm{H}$ dan meninggal pada tahun $592 \mathrm{H}$. Ia mengalami dua masa pemerintahan Andalusia, yaitu pemerintahan Murabitin dan Muwahhidin (Ibn Maḍa, 1979: 5).

Setelah belajar di tempat kelahirannya, Cordova, Ibn Madha pergi menuju Saville. Di sana ia berguru kepada Ibn al-Rumak yang mengajarkan kitab besar karya Sibawaih yang berjudul alKitāb, sebuah karya nahwu aliran Bashrah. Kemudian ia pergi ke Satah untuk belajar ilmu hadits dan fiqh. Di antara guru-gurunya dalam ilmu fiqh dan uṣūl al-fiqh adalah Ibn al-Araby dan Abu Muhamad Ibn al-Manashif dan Iyadh. Sedangkan guru-gurunya bidang kebahasaan adalah Abu Bakar Ibn Sulaiman dan Ibn Basykawal, di samping Ibn al-Rumak (Id, 1989: 38).

Ibn Madha menunjukkan loyalitasnya kepada Khalifah sehingga ia memperoleh perhatiannya dan diangkat menjadi Qadli di Fas, bahkan pada masa pemerintahan Yusuf bin Abd al-Mukmin (558-580 H.) Ia diangkat menjadi Qādi al-Jamā'ah yang berpusat di Maroko (al-Ausi, 1976: 38). Jabatan ini dipangku olehnya dari tahun 578 hingga $582 \mathrm{H}$ (al-Tayyar, 1980: 34). Ini berarti pada masa pemerintahan cucu Abd al-Mukmin, Yakub bin Yusuf (580-585 H) (al-Suyuti, t.t.: 323).

Demikianlah situasi kegiatan intelektual pada masa pemerintahan Murabitin. Kiranya dapat diduga bahwa kemunduran aktivitas intelektual yang dialmi Ibnu Maḍa selama belajar dalam masa pemerintahan Murabitin dan gagasan untuk memperbaiki sistem pendidikan yang diterima dari Ibn al-Arabiy itu sedikit banyak ikut melatarbelakangi ketajaman pandangan dan sikap kritis Ibn Madha, terutama gugatannya terhadap ulama naḥwu(al-Saba, 1978: 38).

\section{Kontribusi Ibnu Mạ̣ā dalam Ușūl al-Nạ̣w}

Dalam ranah kajian ilmu nạ̣wu, munculnya istilah $U s \underline{u} \bar{l}$ al-NaḥW diperkenalkan pertama kali oleh Ibn Shirāj (W 316 H) melalui bukunya Al-Ușül fí al-Nạ̣wi. Kemudian diikuti oleh generasi ahli Naḥwu berikutnya, seperti Ibn Jinni (W 392 H) lewat karyanya Al-Khașāiș, Ibn alAnbari melalui dua bukunya Al-Ighrāb fì Jadāl Al-I'rāb dan Lam' al-Adillah fî Ușūl alNaḥw, serta Imam Al-Suyūṭi dengan kitabnya Al-Iqtirāh fî̀ Ilm Ușūl al-Naḥwi. Meski istilah Ușūl al-Nahwi baru muncul di tangan generasi belakangan, namun bukan berarti sebelumnya diskusi mengenai $U$ șul al-Naḥwi tidak ada. Prinsip-prinsip dasar yang membangun ilmu naḥu sudah ada dalam kajian ilmu nahwu awal (al-Ibadi, 1964: 166), namun belum teristilahkan dan dalam bentuk parsial (Mubarak, 1981: 149-150).

Dalam upaya pembaharuan nahwu, Ibn Madha mengatakan pada awal bukunya al-Radd 'Alà al-Nuhăt bahwa ia ingin membuang bahasan-bahasan yang tidak diperlukan dalam nahwu. Ia ingin meninggalkan penggunaan teori amil dalam menganalisis kalimat, karena penggunaan teori amil itu ternyata berakibat kepada kemunculan teori adanya amil dan ma'mul yang dibuang dan di-

taqdir-kan. Taqdir ini mengakibatkan penambahan kata yang sebenarnya tidak ada atau tidak diperlukan dan bahkan bisa merusak arti semula (Ibn Madha, 1979: 13). Ia menolak penggunaan 
teori taqdir bagi amil dan ma'mul itu, apalagi kalau taqdir itu diterapkan untuk ayat al-Qur' an. Ia mengemukakan gagasan untuk menolak penggunaan teori amil, 'illah dan tamrīnàt iftiraḍiyyah'.

Dalam literatur-literatur ilmu nahwu dijelaskan, bahwa prinsip dasar yang membangun ilmu nahwu atau yang diistilahkan dengan Ușūl al-nậwi terdiri dari empat komponen, yaitu: qiyās, ta' Til (Illah ), ta'wìl dan 'ämil.

\section{Qiyās}

Para ahli Naḥwu Bașrah dan Baghdād sepakat mengenai keberadaan qiyās dalam Naḥwu. Hanya saja, mereka berbeda pendapat mengenai definisi dan batasan-batasannya. Ahli Nahwwu Basrah barangkali dapat digolongkan sebagai orang yang pertama kali mendiskusikan qiyās dalam Naḥw. Hal ini dikarenakan Basrah telah menjadi tempat awal bagi lahir dan berkembangnya Nahwwu. Sementara itu, ahli Nahwu Baghdad hanya turut andil dalam memperluas diskusi mengenai qiyās dan mengembangkan konsepnya. Ketika qiyās telah dijadikan objek kajian oleh para ahli Naḥwu dalam mendiskusikan masalah-masalah bahasa, maka qiyās pun kemudian dijadikan sebagai metode dalam menguraikan dan mengambil patokan dalam menyelesaikan masalah kebahasaan.

Ada empat pilar (rukun) yang menopang qiyās, yaitu maqis alaih, maqis Illah, dan hukum. Sebagian ahli Naḥwu menyebut rukun-rukun tersebut dengan istilah lain, yaitu asal (așI), cabang (far'u), sebab (Illah) dan hukum.

Praktik qiyās seperti itu secara lebih gamblang dapat digambarkan dalam sebuah contoh. Misalnya firman Allah dalam surat al-Baqarah ayat 184:

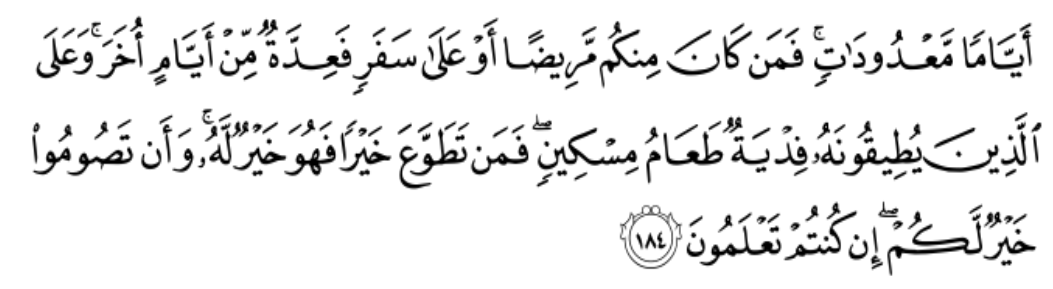

Kalimat an tașumū merupakan mașdar muawwal yang berkedudukan sebagai mubtada' dan berhukum marfü'. Mubtada' adalah asal, sedangkan mașdar muawwal merupakan cabang (far'u). Rafa'merupakan hukum, sedangkan Illah (sebab) yang mempertemukan antara keduanya adalah tidak di-isnad-kannya kata tersebut dengan 'Amil lafzhi.

Qiyās, menurut Ibn Madhā, apabila digunakan dalam dalam bahasa (ilmu nahwu) bukan merupakan hal yang dilarang. Ia membolehkan qiyās. Hanya saja, qiyās yang dibolehkan adalah qiyās yang disertai dengan bukti teks yang jelas. Apabila tidak ditemukan bukti teks yang jelas, yang dapat menguatkan sesuatu yang di-qiyās -kan, maka qiyās seperti ini tidak dapat diterima dan bahkan harus ditolak. Tampaknya, pemikiran Ibn Madha ${ }^{-}$tentang qiyās ini memiliki keterkaitan dengan pemikirannya tentang teks linguistik.

Di dalam bab tanāzu', Ibn Madha secara tegas menolak untuk meng-qiyās -kan ma'mūlāt seperti dharaf, mașdar dan hāl kepada maf'ūl. Ia baru menerima pengqiyāsan itu apabila di dalamnya ditemukan bukti (teks/bahasa) yang datang (didengar) dari orang Arab.

Menurut pertimbangan Ibn Madha, bentuk mașdar semestinya dihadirkan untuk meneguhkan (ta'kid) fi'il. Membuang masdar berarti bertentangan dengan prinsip peneguhan itu sendiri.

Ibn Madha secara tegas menolak qiyās aqti. Menurutnya, para nuhāt tidak jeli dan cermat ketika menjadikan model qiyās seperti ini di dalam kajian-kajian linguistik (ilmu $\mathrm{Nah} w u$ ) mereka. Hal ini karena mereka telah membawa sesuatu kepada sesuatu yang lain dengan tanpa adanya hubungan atau keterkaitan yang konprehensif dalam meng-qiyās -kan dua hal tersebut. Di samping itu, mereka mengira bahwa praktik yang seperti itu (menggunakan qiyās aqli) juga dikehendaki oleh masyarakat Arab. Dengan jelas Ibn Madha mengatakan: 


\section{Arabi : Journal of Arabic Studies}

"Orang Arab adalah umat yang cerdas. Bagaimana mungkin mereka menyamakan sesuatu dengan sesuatu yang lain, dan menyamakan hukum sesuatu itu pada sesuatu yang lain, sementara sebab hukum asal tidak ditemukan dalam cabang? Jika di antara para nuhät ada yang melakukan seperti itu, berarti ia bodoh dan tidak bisa diterima. Mengapa mereka menisbatkan sesuatu yang tidak diketahui oleh sebagian mereka kepada orang Arab? Ini semua karena mereka tidak meng-qiyās-kan sesuatu dan memberlakukan hukumnya kecuali apabila sebab hukum asal ditemukan pada cabang" (Ibn Mada, 1947: 156).

Dari pernyataan tersebut, jelas bahwa Ibn Madha menolak jenis qiyās seperti ini berdasarkan pada dua prinsip:

\section{Pertama, Alasan Rasional}

Alasan rasional yaitu bahwa prinsip menyamakan dua hal karena adanya kesamaan sebab (antara hukum asal dengan cabang) merupakan prinsip yang lemah. Karena, bentuk kesamaan (al-mushabbahah) yang terdapat dalam asal dan cabang tidak sempurna. Kedua, alasan linguistik. Yakni, bahwa orang Arab belum tentu atau memang tidak sama sekali menghendaki apa yang dilakukan oleh para nuhät. Dengan kata lain, bahwa praktik penggunaan qiyās aqli diingkari oleh Ibn Madha karena tidak memiliki keterkaitan dengan praktik berbahasa orang Arab itu sendiri atau memang masyarakat Arab tidak pernah menggunakan qiyās aqli dalam menggunakan bahasa mereka sehari-hari.

\section{Kedua, Alasan Linguistik}

Yakni, bahwa orang Arab belum tentu atau memang tidak sama sekali menghendaki apa yang dilakukan oleh para nuhät. Dengan kata lain, bahwa praktik penggunaan qiyās aqli diingkari oleh Ibn Madha karena tidak memiliki keterkaitan dengan praktik berbahasa orang Arab itu sendiri atau memang masyarakat Arab tidak pernah menggunakan qiyās aqli dalam menggunakan bahasa mereka sehari-hari.

\section{Ta'Til (Illah)}

Ta'Til merupakan salah satu metode untuk mencari hukum bahasa yang digunakan dalam ilmu nạ̣wu (al-istidlāl al-nạ̣wi). Secara etimologi, ta'fil berarti mencari Illah (sebab), baik langsung maupun tidak langsung, yang berujung pada suatu kesimpulan tertentu, baik kesimpulan ini bersifat murni logis maupun bersifat alami. Sedangkan Illah secara bahasa berarti sebuah makna yang menempati suatu posisi di mana posisi yang ditempati itu berubah karenanya dengan tanpa sengaja (al-Hifni, 1990: 213).

Fenomena ta'Til dalam Naḥwu seringkali dapat ditemukan dalam bentuk yang beragam. Ta'Til ini menjelma dan tersebar di dalam berbagai tema kajian Naḥwu. Di antaranya, i'rāb fi'il muḍari karena kesamaannya dengan isim dan ke-mabni-an sebagian isim karena kesamaannya dengan huruf dengan berdasarkan pada Illah tashbihiyah. Contohnya, membuang huruf wawu dalam kata ya'idu (يعد) asal kata و عد. Huruf wawu dibuang, karena berada di antara huruf ya' dan kasrah; alasan pembuangannya adalah karena menghindari pengucapan yang berat.

Illah juga dikenal dalam ilmu filsafat. Apabila dalam ilmu filsafat, illah dibagi menjadi empat. Yaitu, Illah mādiyah (causa materialis), süriyah (causa formalis), fá'iliyah (causa efficiens) dan gha'iyah (causa finalis). Illah mädiyah berarti sebab yang mengharuskan adanya akibat (ma'lūt) karena kekuatannya, seperti kayu dan besi jika dinisbatkan kepada tempat tidur. Illah süriyah adalah jenis yang menentukan bentuk sesuatu atau sesuatu yang diakibatkan oleh perbuatan seperti bentuk jika dinisbatkan kepada tempat tidur. Illah fá'iliyah adalah akibat yang ditimbulkan karena adanya sebab, seperti tukang kayu jika dinisbatkan kepada tempat tidur. Sementara Illah ghai'iyah adalah akibat yang ditimbulkan oleh akibat. Atau dengan kata lain, Illah gha'iyah adalah Illah al-ilāl (akibat dari akibat), seperti posisi duduk jika dinisbatkan kepada tempat tidur (al-Hifni, 1990: 214).

Apabila Illah-Illah tersebut digunakan dalam bentuk pertanyaan, maka wujudnya adalah Illah mādiyah berarti "Apakah sesuatu itu?", Illah șüriyah berarti "Bagaimana sesuatu itu?", 
Illah făiliyah berarti "Siapakah yang melakukan sesuatu itu?" dan Illah gha'iyah berarti "kenapa sesuatu itu?"

Hal ini terjadi dalam berbagai lini/aspek kehidupan, tak terkecuali pada pembahasan ilmu nahwu. Dalamilmu nahwu, premis-premis Illah tersebut mengarah kepada bentuk Illah gha'iyah. Maka, pertanyaan "Kenapa?" menjadi suatu keharusan dalam ilmu nahwu (Ied, 1989: 115).

Untuk lebih memfokuskan pada kajian ilmu nahwu, maka akan dibahas klasifikasi illah dalam kajian nahwu. Secara global, Illah dalam nahwu dikelompokkan menjadi tiga macam:

\section{Pertama, Illah ta'Timiyah}

Illah ta'Timiyah yaitu illah yang dapat menunjukkan seseorang untuk mengetahui atau memahami bahasa orang Arab, seperti ungkapan إنّ الامتحان قريب. Jika ditanyakan kenapa kata al-imtihāna dibaca naṣablfathah?, maka jawabannya adalah karena kata inna menașabkan isimnya dan merafakkan khabarnya, dan memang demikianlah kita mengetahuinya dari orang Arab.

\section{Kedua, Illah qiyāsiyah}

Seperti dalam contoh terdahulu, إنّ الامنحان قريب, jika ditanyakan kenapa kata al-imtihāna dibaca nașab/fathah?, maka jawabannya adalah karena kata inna dan saudaranya menyerupai fi'il muta'addi yang menașabkan maf'ühya. Karena persamaan itulah, maka inna dan saudaranya bisa berfungsi sebagaimana fi'il muta'addi. Maka, dalam konteks ini kata al-imtihāna serupa dengan maf'ül bih secara lafżi, sementara inna adalah fi'il yang menașabkannya.

\section{Ketiga, Illah jadaliyah nazariyah}

Illah jadaliyah nazariyah yakni alasan (illah ) yang dikemukakan dalam illah qiyās iyah. Dalam kasus contoh di atas, Illah ini dapat berupa bentuk pertanyaan: "Dari perspektif apa inna bisa disamakan dengan fi'il?", "Dengan fi'il apakah?", "Apakah fi'il mādi, muḍariri atau amr?' dan seterusnya (Ied, 1989: 119).

Sementara di sisi lain, Ibn Madha berpendapat bahwa illah dibagi menjadi dua macam, Illah ülā (illah lapisan pertama) dan illah thawāni (illah lapisan kedua, ketiga dan seterusnya). Illah ülämerupakan alasan yang dengannya seseorang dapat memahami perkataan atau ucapan orang Arab. Illah ini dapat dikategorikan sebagai dasar untuk menetapkan aturan main (struktur dasar) yang dipakai dalam bahasa orang Arab. Sementara itu, Illah tsawani menurut Ibnu Maḍa, tidak diperlukan (Ibn Madha, 1947: 152).

Ketika Ibn Madha ditanya mengapa kata Zaid dalam kalimat qāma zaidun harus dibaca rafa?, Ia menjawab: karena kata itu berkedudukan menjadi fa'il dan fa'il itu harus dibaca rafa'. Inilah yang disebut dengan alasan pertama (illah $\bar{u} l \bar{a})$. Jika kemudian ditanya lagi kenapa fa' $i l$ itu harus dibaca rafa', maka menurut Ibn Madha pertanyaan itu tidak pat ut dijawab. Jawaban yang pas tidak lain adalah karena begitulah orang Arab mengatakan.

Pandangan seperti ini tentunya jauh berbeda dengan pandangan mayoritas nuhät sebelumnya. Jika pertanyaan serupa diajukan kepada nuhät yang lain, maka mereka pasti memberikan jawaban: kata zaid dibaca rafa' karena fá'il dan fá'il itu harus rafa' (illah $\bar{u} l \bar{a})$; kenapa harus rafa'? karena untuk membedakan antara fá'il dengan maf'ül(illah thäniyah); kenapa fá'il tidak dibaca nașab saja dan maf'ül dirafa'kan? Karena fá'il itu sedikit, sedangkan maf'ūl itu bisa banyak (illah thālithah). Bagi Ibn Madha, illah thāniyah dan seterusnya tidak diperlukan ketika seseorang memakai bahasa Arab karena hanya menimbulkan perdebatan yang sia-sia. Ibn Madha menyatakan:

"Hal yang harus dihilangkan dalam Nahwwu adalah perdebatan yang tidak patut diangkat seperti perdebatan para nuhät mengenai Illah rafa'nya fá'il, nasabnya maf' $\bar{u} l$ bih dan seluruh perdebatan mereka mengenai Illah tsawani yang tidak patut dikemukakan" (Ibn Madha, 1947: 164).

Ibn Madha juga membagi illah thawāni ke dalam tiga macam. Yaitu, maqț $\bar{u}$ ' bih, mā fỉhi iqnā' dan maqtù' bi fasadihi. Yang pertama dimaksudkan sebagai 'illah yang harus dihilangkan 


\section{Arabi : Journal of Arabic Studies}

melalui pemutusan pertanyaan. Setelah 'illah pertama tidak diperbolehkan lagi mengajukan illah kedua. Yang kedua dimaksudkan sebagai illah yang di dalamnya terdapat perasaan puas demi kepentingan pencarian persamaan di antara dua hal (asal dan cabang). Sementara yang ketiga dimaksudkan sebagai 'illah yang memang tidak memiliki manfaat dan arti apa-apa ketika diungkapkan atau bahkan tidak dapat memuaskan akal dan memang benar-benar tidak memiliki signifikansi bagi penalaran (Ibn Madha, 1947: 152).

\section{Ta'wïl}

Secara etimologi, ta'will berarti merenungkan, mengira-ngira dan menafsirkan. Sedangkan secara terminologi, ta'wil berarti menggeser zahimya teks (lafaz) dari posisinya yang otentik menuju bukti (makna) yang dibutuhkan seolah-oleh makna itu meninggalkan zāhir dari teks. Atau dengan kata lain, ta'wil adalah menafsirkan ucapan yang maknanya berbeda-beda dengan memberikan penjelasan yang diambil dari luar teks (Manzhur, 1996: 264).

Dalam Islam, ta'wïl telah menjadi terminologi yang signifikan, yang diperdebatkan oleh aliran-aliran atau mazhab-mazhab pemikiran. Masing-masing aliran memiliki prinsip dan pijakan. Masing-masing menisbatkan dirinya kepada Islam dan mengklaim berpegang teguh pada Alquran dan Hadis. Dengan penerimaan dan penolakannya terhadap ta'wil, masingmasing aliran membaca dan memahami teks-teks keagamaan (Alquran dan Hadis). Hal ini juga yang mengakibatkan mereka berbeda pendapat dalam pemahaman mengenai suatu ayat. Ada yang cenderung rasional, tetapi ada juga yang cenderung lebih literal.

Di kalangan mayoritas mufassir, kata ta'wil didefinisikan sebagai upaya mengalihkan kalam dari sisi literalnya menuju permenungan dan pemahaman yang lebih luas. Sementara dalam tradisi fiqh, ta'will didefinisikan sebagai usaha untuk mengalihkan lafaz dari makna literalnya menuju kemungkinan makna yang lain yang dipandang masih sesuai dengan teks itu sendiri (Al Jurjani, 1988: 50). Sementara itu, dalam tradisi sastra, ta'wïl diartikan sebagai usaha memberi makna tertentu pada teks untuk mendapatkan signifikansi sebuah cerita (Wahbah dan Al Muhandis, 1984: 86).

Dalam ilmu naḥwu ta'wīl dijadikan sebagai metode untuk membuat hukum-hukum atau aturan-aturan bahasa Arab. Para nuhät menggunakan ta'wìl untuk menafsirkan ungkapan atau teks dari sisi literalnya agar sesuai dengan aturan-aturan dan hukum-hukum Nahwu. Praktik ta'wīl dapat ditemukan secara luas dalam berbagai buku Naḥwu. Secara nyata, metode ta'wīl dalam ilmu nahwu menjelma menjadi konsep hadhaf (pembuangan), istitär (penyembunyian) dan taqdir (pengiraan) dalam sebuah kalimat. Contohnya, pembuangan fi'il dalam perintah (amr) dan larangan (nahy):

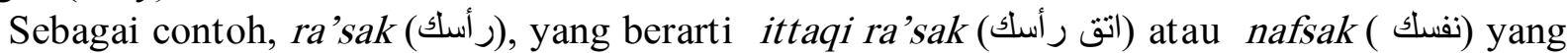

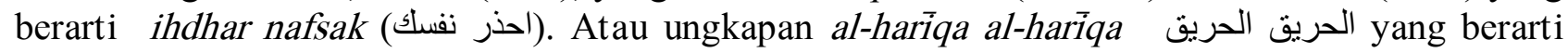
ihdhar al-hariqa (احذر الحريق) (Ibn Qumbur, 1966: 275). Begitu juga misalnya dalam sumpah:

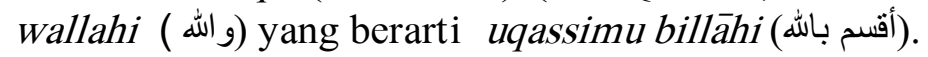

Ada dua point penting terkait dengan muḍmar dan mahdhüf, yang harus dicermati secara kritis. Pertama, yang mudmar berarti sesuatu yang harus dipenuhi, sementara yang mahzüf berarti sesuatu yang tidak diperlukan. Kedua, yang muḍar adalah isim, sementara yang mahdhüf adalah fi'il. Hadhaf (pembuangan) hanya terjadi pada fi'il dan jumlah, dan tidak berlaku pada isim. Kedua point itu tidak memberikan garis pembedaan yang jelas dan cermat. Bahkan cenderung kontradikstif dan ambigu. Menurut Ibn Madha, satu-satunya yang dapat membedakan kedua hal itu tidak lain dikembalikan kepada si penutur (mutakallim) bahasa itu sendiri (Ibn Madha, 1947: 102).

Ibn Madha berpendapat, ada tiga jenis mahdhüfat, yaitu:

Pertama, kata dibuang karena lawan bicara (orang kedua) diindikasikan telah mengetahui. Misalnya, ketika dikatakan zaidan yang berarti a'thi zaidan. Hal ini terjadi 
karena lawan bicara dianggap telah mengetahui "perintah untuk memberi sesuatu" kepada si Zaid, sehingga cukup dikatakan zaidan saja.

Kedua, kata itu dibuang karena memang tidak dibutuhkan dan bahkan jika masih tetap ditampakkan maka akan merusak ucapan, seperti azaidan dharabtahu?

Ketiga, kata itu dibuang karena jika tetap ditampakkan maka disinyalir dapat merubah ucapan, seperti yā abdallah...! Jika ucapan ini ditampakkan menjadi ad'ù abdallah maka strukturnya menjadi berubah. Yaitu, dari bentuk nidā' (panggilan) menjadi bentuk khabariyah (berita) (Ibn Madha, 1947: 88). Atas dasar itulah, Ibn Madha hanya menerima konsep mahdhüf (pembuangan) manakala pembuangan tersebut telah diketahui oleh lawan bicara (mukhätab). Sejauh lawan bicara (mukhätab) mengerti atau mengetahui hadhaf (delasi) kata/kalimat yang dikehendaki oleh si mutakallim (penutur), maka sejauh itu pula boleh dilakukan delasi (hadhaf). Tetapi jika tidak mengetahui, maka lawan bicara (mukhătab), maka tidak diperbolehkan melakukan pembuangan tersebut.

Menurut Ibn Madha, dalālah dibagi menjadi dua macam, yaitu:

Pertama, dalālah lafziyah yang dikehendaki oleh si pemakai bahasa (al-waḍi') seperti dalālah isim dengan sesuatu yang dinamai (al-musammā) dan dalālah fíil dengan peristiwa dan waktu.

Kedua, dalālah luzūmiyah seperti dalālah-nya atap dengan tembok. Dalālah fíil atas fá'il tidak lain adalah dalālah lafżyah. Maka, dalam kata kerja -misalnya saja- kata ya'lamu, a'lamu dan na'lamu, tidak ada istilah yang disebut dengan iḍmār (penyembunyian). Huruf yā', sebagaimana dalam fi'il mudhari' berarti tanda bagi bentuk huwa (seorang ketiga laki-laki), alif berarti ana /orang pertama (penutur sendiri) dan nūn berarti nahnupenutur dalam jumlah banyak (Ibn Madha, 1947: 103-105).

Pada titik ini, agaknya pandangan Ibn Madha selaras dengan pikiran-pikiran yang dilontarkan oleh para linguistik modern mengenai morfologi seperti Bergstrasser. Kritikan yang tajam sebagaimana dikemukakan oleh Ibn Madha ini juga diikuti oleh para ahli linguistik Arab modern, yaitu bahwa para nuhät telah melakukan pentakwilan terhadap teksteks yang sebenarnya tidak butuh pada pentakwilan itu sendiri (al-Mathlaby, 1986: 92).

\section{$\bar{A}$ mil}

$\bar{A}$ mil dalam ilmu nahwu bisa digolongkan sebagai pilar utama. Biasanya, dikenal ada dua jenis $\bar{A} m i l$, yaitu lafẓi dan ma'nawi. Amil lafazi berbentuk lafaz secara nyata, sedangkan Amil ma'nawi biasanya tidak berwujud lafaz dan tidak memiliki pengaruh secara nyata terhadap keberadaan kata yang lain.

Di samping itu, para nuhāt juga memandang adanya dua jenis āmil., yaitu, āmil yang memiliki pengaruh secara nyata berupa harakat atau syakal dan atau huruf yang terdapat di akhir kalimat. Sedangkan yang kedua adalah āmil yang kehadirannya bersifat tidak nyata karena alasan keserupaan atau kedekatan. Ibn Madha menolak jenis āmil yang pertama. Menurutnya, yang paling berperan dalam merubah maksud ucapan tidak lain adalah si penutur (mutakallim) itu sendiri, bukan àmil. Hal ini karena àmil itu mengisyaratkan adanya waktu saat melakukan sesuatu dan mestinya si àmil itu melakukannya dengan kehendak atau secara alami (Ibn Madha, 1947: 87).

Menurut Ibn Madha, salah satu contoh ketidak-rasionalan para nuhāt dalam menggunakan konsep āmil adalah penerimaan āmil ibtidā' yang diyakini ada pada jumlah mubtada'-khabar. Yaitu, bahwa mubtada' itu dirafakan oleh adanya Amil ibtidā'. Yang merafakan mubtada' tidak lain—menurut Ibn Madha —adalah si mutakallim itu sendiri dan bukan àmil ibtidā', karena tindakan merafakan itu menyertai si mutakallim dan bukan àmil ibtidā' seperti yang diyakini oleh para nuhät.

Begitulah penolakan Ibn Madha terhadap praktik qiyās, illah, āmil dan ta'wīl. Pandangan Ibn Madha berpijak pada apa yang oleh kalangan nuhăt disebut dengan sama'i. Artinya, bahwa Ibn 


\section{Arabi : Journal of Arabic Studies}

Madha membolehkan praktik semua pilar itu sebagai metode dalam ilmu nahwu sejauh ditemukan bukti tekstual yang datang dari orang Arab sendiri.

Ibn Madha bukanlah satu-satunya nuhăt yang melakukan rekonstruks di bidang ilmu naḥwu. Ada banyak sekali nuhăt yang melakukannya pula terutama pada masa setelahnya, sebagai mana dipaparkan dalam Disertasi karya Dr. Rofi'i, M. A. tentang kontribusi nuhăt pada abad XX. Berikut ini adalah hasil pemikiran para nuḥät tersebut:

\begin{tabular}{|c|c|c|c|}
\hline Ibn Madha & Ibrāhỉm Musțafá & Hasan Kāmil & Majma' al-Lughah \\
\hline $\begin{array}{l}\text { - Membuang } \\
\text { penggunaan teori } \\
\text { 'ámil } \\
\text { - Membuang teori } \\
\text { 'illah kedua dan } \\
\text { ketiga } \\
\text { - Membuang } \\
\text { tamrināt } \\
\text { iftiradiyyah } \\
\text { - Menjanjikan } \\
\text { nahwutanpa } \\
\text { 'àmil } \\
\text { Analisis kalimat } \\
\text { didasarkan pada } \\
\text { makna, } \\
\text { contohnya } \\
\text { ishtighāl, tanāzu' } \\
\text { dan nașab fi'il } \\
\text { mudhari' }\end{array}$ & 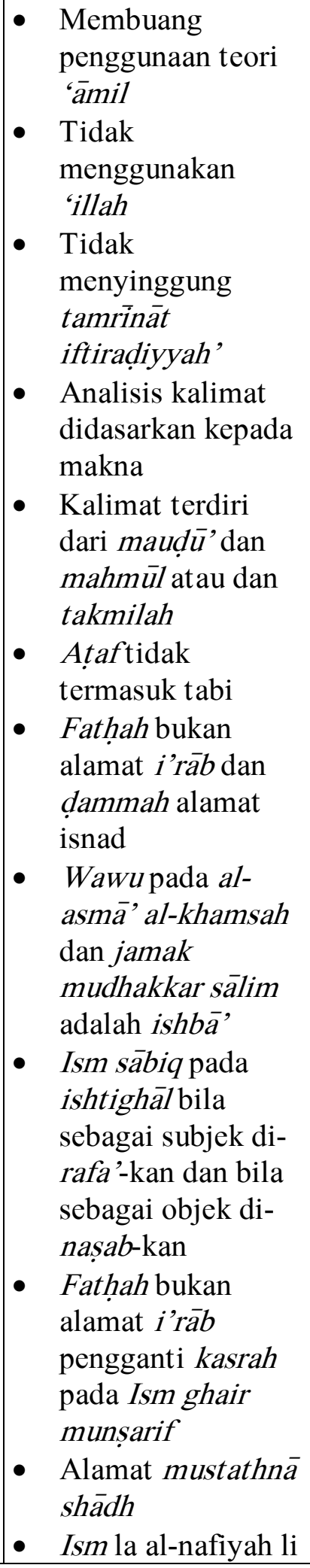 & 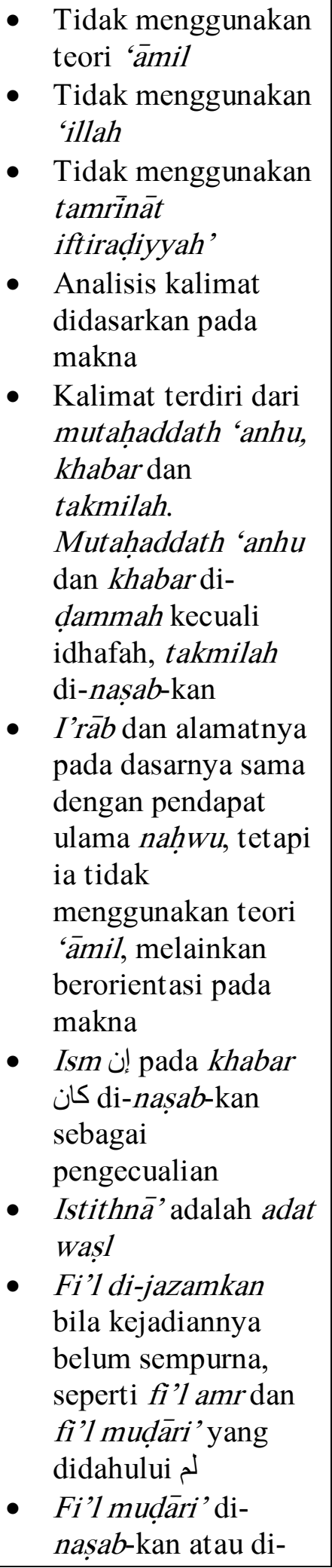 & 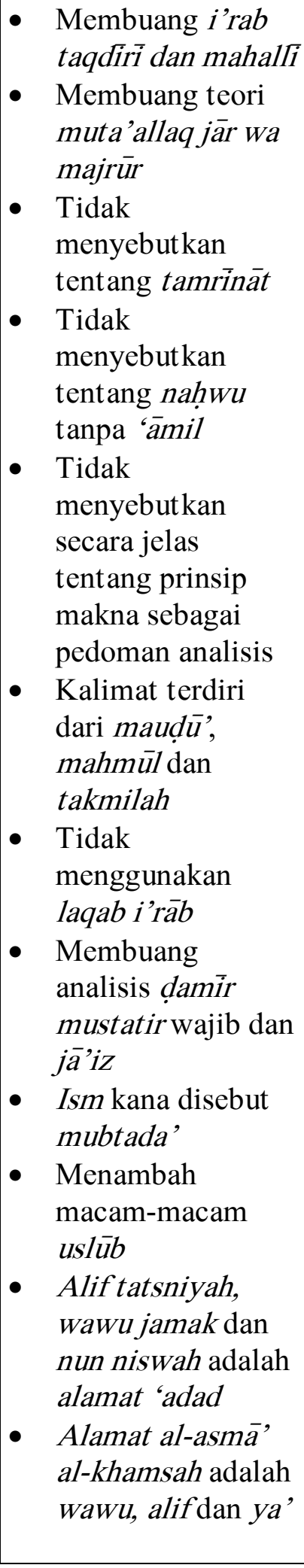 \\
\hline
\end{tabular}




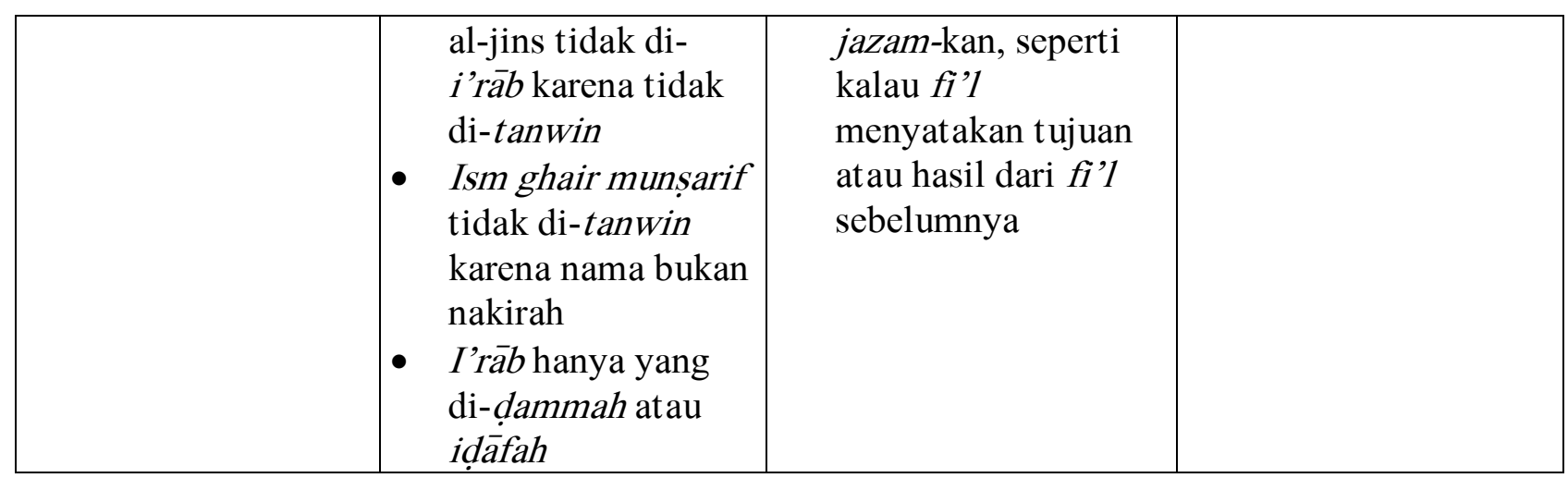

\section{Simpulan}

Ibn Madha merupakan salah satu tokoh nuhät yang sangat terkenal pada masnya. Hal ini disebabkan oleh pemikiran-pemikirannya yang cenderung kontradiktif dengan para nuhăt pada masanya sebagai mana tertuang dalam karya besarnya "al-Radd 'Alā al-Nuḥât". Ușūl Al-Naḥwi terdiri dari empat komponen, yaitu: qiyās, ta'iil (Illah ), ta'wīl dan 'ämil. Ibn Madha secara tegas menolak qiyās aqli, Ibn Madha juga hanya menerima Illah Ūlā dan tidak menerima illah thawāni. Secara nyata, metode ta'wīl dalam ilmu naḥwu menjelma menjadi konsep hadhaf(delasi), istitär (penyembunyian) dan taqdir (pengiraan) dalam sebuah kalimat, dan Ibn Madha tidak menerima hal tersebut begitu juga dengan āmil lafżi. Begitulah penolakan Ibn Madha terhadap praktik qiyās, illah, àmil dan ta'will. Pandangan Ibn Madha berpijak pada apa yang oleh kalangan nuhät disebut dengan samā'i.[]

\section{Daftar Rujukan}

al-Ausi, Himah Ali. 1976. al-Adab al-Andalusi fi 'Ash al-Muwahhidin, Kairo: Maktabah al-Khanji. al-Hifni, Abdul Mun'im. Al-Mu'jam al-Falsafí, Mesir: Dār al-Sharqiyah, 1990

al-Ibādì, Abd al-Ḥāmid. 1964. al-Mujmal fī Tārikh al-Andalūsī, Kairo: Dār al-Qalam. Ke-2

Ied, Muhammad. 1979. Ușūl al-Naḥwi al-Arabi fỉ Nazri al-Nuhăt wa Ra'yi fî Dau'i 'Ilm al-Hadith, Kairo: A'lām al-Kutub.

Ibn Madha. 1979. al-Radd 'Alā al-Nuḥât, tahqīq Muhamad Ibrahim al-Bannā', Kairo: Dār alI’tișām, Cet. Ke-1

Ibn Madha. 1989. Madā wa ḍau'i Ilm al-Lughah al-Hadits, Kairo: Alam al-Kutub.

Ibn Qambūr, Abi Basyar Amr bin Utsman. 1966. Kitāb Sibawaeih, ditahqiq oleh Abdusalam Muhammad Hārūn, Mesir: Dār al-Qalam.

Mubarak, Mazin. 1981. al-Nahwu al-'Arabiy, al-'Illat al-Naḥwiyyah Nash'atuhā wa Tatawwuruhā, Beirūt: Dār al-Fikr, Cet. Ke-2.

al-Saba', Taufiq Muhamad. 1978. Athar al-Fikr al-Falsafi fí al-Dirāsāt al-Naḥwiyyah dalam majalah Kulliyyat al-Lughat al-'Arabiyyah, no. VII.

al-Jurjānī, Ali Muhammad. Kitab at-Ta’rífät, Beirut: Dār al-Kutub al-Ilmiyyah, 1988

al-Mațlabi, Malik Yusuf. 1986. Al-Zamān wa al-Lughah, Mesir: Al-Hai'ah al-Mișriyah al'Āmmah li al-Kitāb.

al-Suyūțì, Abd. Al-Rahman Jalaluddin. t.t. Bughyāt al-Mu'ah fí Tabaqāt al-Lughawiyyin wa alNuḥät, Beirūt: al-Maktabah al-'Așriyyah, Jilid I

al-Ṭayyār, Riḍ̄a Abd. Al-JaTil. 1980. al-Dirāāàt al-Lughawiyyah fỉ al-Andalus, Irak: Dār al-Rashīd.

Wahbah, Majdi. dan Kamil Al-Muhandis. 1984. Mu’jam al-Muṣtalahāt al-Arabiyah fí alLughah wa al-Adab, Beirut: Maktabah Lubnān. 